\title{
A compilation on the application dimension of creative drama and bibliotherapy method in education
}

\section{Uma compilação sobre a dimensão de aplicação do drama criativo e do método de biblioterapia na educação}

\section{Una recopilación sobre la dimensión de aplicación del método dramático creativo y la biblioterapia en la educación}

\author{
Şengül Başarı ${ }^{1}$ iD, Seçil Besim Ayhan ${ }^{1}$ iD
}

\author{
${ }^{1}$ Near East University, Cyprus, Turkey. \\ Corresponding author: \\ Author's full name: Şengül Başarı \\ Email: sengul.basari@neu.edu.tr
}

How to cite: Başarı, S., \& Ayhan, S. B. (2021). A compilation on the application dimension of creative drama and bibliotherapy method in education. Revista Tempos e Espaços em Educação, 14(33), e15662.

http://dx.doi.org/10.20952/revtee.v14i33.15619

\begin{abstract}
Creative drama and bibliotherapy are among the most frequently mentioned methods in the field of education recently. The applicability of Creative Drama as a method in many areas is revealed by different studies, and bibliotherapy is becoming widespread as an effective method, especially in the fields of Guidance and Psychological Counseling, Psychology and Psychiatry. From this point of view, the objective of this study is to synthesize and display the importance and field of application of these two methods through different studies and to contribute to the formation of a perspective as regards the usage of these methods by educators. For this purpose, a review was prepared by examining the studies on creative drama and bibliotherapy. Descriptive survey method was used in the research. National and international literature was surveyed and the articles obtained as a result of the research were evaluated and interpreted in general.
\end{abstract}

Keywords: Creative drama. Bibliotherapy. Education. Student.

\section{RESUMO:}

O drama criativo e a biblioterapia estão entre os métodos mais mencionados no campo da educação recentemente. A aplicabilidade do Drama Criativo como método em diversas áreas é revelada por diversos estudos, e a biblioterapia vem se difundindo como método eficaz, principalmente nas áreas de Orientação e Aconselhamento Psicológico, Psicologia e Psiquiatria. Desse ponto de vista, o objetivo deste estudo é sintetizar e evidenciar a importância e o campo de aplicação desses dois métodos por meio de estudos distintos e contribuir para a formação de uma perspectiva quanto ao 
uso desses métodos por educadores. Para tanto, elaborou-se uma revisão examinando os estudos sobre drama criativo e biblioterapia. O método de levantamento descritivo foi utilizado na pesquisa. Levantou-se a literatura nacional e internacional e os artigos obtidos como resultado da pesquisa foram avaliados e interpretados de forma geral.

Palavras-chave: Drama criativo. Biblioterapia. Educação. Aluno.

\section{RESUMEN}

El drama creativo y la biblioterapia se encuentran entre los métodos más mencionados en el campo de la educación en los últimos tiempos. La aplicabilidad del Drama Creativo como método en muchas áreas es revelada por diferentes estudios, y la biblioterapia se está generalizando como método efectivo, especialmente en los campos de Orientación y Consejería Psicológica, Psicología y Psiquiatría. Desde este punto de vista, el objetivo de este estudio es sintetizar y mostrar la importancia y campo de aplicación de estos dos métodos a través de diferentes estudios y contribuir a la formación de una perspectiva sobre el uso de estos métodos por parte de los educadores. Para ello, se elaboró una revisión examinando los estudios sobre drama creativo y biblioterapia. En la investigación se utilizó el método de encuesta descriptiva. Se relevó la literatura nacional e internacional y se evaluaron e interpretaron en general los artículos obtenidos como resultado de la investigación.

Palabras clave: Drama creativo. Biblioterapia. Educación. Estudiante.

\section{INTRODUCTION}

In modern education approach, it is necessary to place at the foundation of the education system the understanding that teaches students how to reach them rather than how to store them. This has led to the development of several learning models and teaching methods that allow knowledge to be discovered by the students themselves. Today, creative drama, which is seen as a method that enables the individual to be active in the learning process, enables them to learn by doing and living, contributes to self-realization and being a creative and productive individual, in short, to the development of the individual in all aspects, has begun to be used (Kaf, 2000).

In essence, creative drama is expressed as a kind of drama formed by the action of doing, or in conceptual dimension, as a process of learning by doing and living when completed. Drama encompasses the process between the starting point and the ending point of any subjective and social situation, and it is a circumstance that arises in the whole process. Dorothy Heathcote emphasizes that drama was a passion and that drama had no boundaries just as passions know no boundaries. According to her, drama is not just a retelling of stories, but situations that individuals encounter. Thanks to these situations which lead to a change in the individual, people learn to cope with the events they experience (Uşaklı, 2007; Vural \& Sommers, 2012; Besim, 2019).

Creative drama in education is the realization of a group work using theater or drama techniques such as improvisation and role playing. Within such efforts, it is the interpretation and animation of an experience, an event, an idea, sometimes an abstract concept or a behavior in "playful" processes in which their former cognitive patterns are reviewed (San, 2002). It is stated that the function of drama in education and training is very important. It is emphasized that the purpose of using drama as a game and its application as a teaching method in education is to develop affective, cognitive and behavioral dimensions. It is frequently emphasized in the literature that the drama technique is an effective way that gives self-confidence, self-knowledge, creativity, critical perspective, self-transcendence, problem solving and solution-production (Genç, 2003).

It is also seen that using drama as a method in education allows for the organization of social relations of contemporary person, letting one know himself, produce, and continue his/her existence. It is especially stated that individuals can easily learn the events and situations and the connections between them through creative drama. It is also argued that creative drama is told 
indirectly, so it is possible to observe the behavior of others and one's own behavior from a safe distance. It is emphasized that today's problems can be searched in the past and in the future. It has also been observed that a situation in the drama is explored with both concrete and abstract expressions. It is stated in the literature that drama is used as an active method involving the development of events. In this case, it can be said that drama concretizes many elements and clarifies the situation. From a sociological point of view, it is emphasized that individuals can have more in-depth knowledge not only about themselves but also about the past, present and future of the society in which they live (O'Neill \& Lambert, 1995; San, 1996; Adıgüzel, 2006).

Heathcote stated that the main core of creative drama is in ensemble (Heathcote \& Wagner, 1990). It is said that drama, which is a group work based on play, is a useful method for students to bring together and combine their differences with a social expression. It is stated that individuals participating in creative drama activities test their own experiences and perspectives against others, see where they differ and on which subjects they are similar. Thus, it is observed that individuals have demonstrated important skills in establishing comfortable and healthy relationships with others as well as a sense of belonging (Johnson \& O'Neill, 1984; Adıgüzel, 1993). It is also stated that drama in education, when in competent hands, will offer the participant the opportunity to exist in a dramatic environment through mental, physical and emotional participation. It is stated that this environment will make an important contribution to the development of skills such as realizing one's own potential, expressing oneself, developing creativity, and being able to think in the shoes of others. In addition, it is emphasized that it will make individuals happy (Sağlam, 2004).

It is seen that creative drama method makes essential contributions to the socialization of the individual (Besim, 2019). It has been observed that social skills have an important place in ensuring socialization. The concept of social skill has been defined by many researchers.

It has been underlined that social skills, which are defined as the ability to behave in accordance with the social environment, play an important role in facilitating the ability to express positive or negative emotions appropriately, defend personal rights, seek help from others when necessary, and refuse requests that are not suitable for oneself (Sorias, 1986). Kelly (1982) defined social skill as learned behaviors used in interpersonal relationship situations that provide or maintain positive reinforcement from the environment. Westwood (1993) expressed social skills as important behavioral elements for individuals to initiate and maintain positive interactions with others. On the other hand, Cartledge and Milburn (1983) defined social skills as behaviors that prevent negative reactions in interaction with others and allow positive reactions, are socially appropriate, vary depending on the social context for the purpose, which are also specific to the situation.

Although social and personal development is among the written goals in our education system, it is seen that the goals in practice mostly focus on competition and academic success. However, social behaviors and skills need to be developed in order for individuals to effectively deal with problems such as violence, alienation and social isolation (Oral, 2002). It is seen that teachers need social control skills while organizing activities involving the whole classroom, planning the class in a way to make the student active, organizing group activities, and keeping up with the environment in an unexpected situation or in case of disruption of plans. The teacher's affective and social sensitivity comes to the fore when dealing with the student's personal problems and concerns. As a matter of fact, it is stated that teachers who are affectively sensitive understand the culture of the period the students are in and act accordingly. An effective teacher who is open to improvement values students' feelings and helps them develop a positive self-concept. It can also be said that students value verbal and non-verbal reactions of such teachers and listen to them. Teachers' roles as listeners and first communicators require them to be affective and socially sensitive. It is stated that teachers' ability to communicate well with students and other staff is related to being expressive and sensitive in emotional and social aspects (Yüksel, 2001). 
It is seen that rapidly changing social structures and rules are making adaptation of students to themselves and their environment more difficult and that more emphasis is put on academic teaching in our education system. It is also observed that as teaching is mostly performed through transfer of knowledge, socialization, which is one of the fundamental goals of education, always remains in the background. It is stated that creative drama method is one of the appropriate teaching methods in ensuring that social skills are gained by individuals as it allows for learning by doing and living. It is observed that creative drama activities have an impact on the social adaptation (Uysal, 1996) and socialization level of individuals (Akın, 1993). Another method in supporting the emotional and social development of students is bibliotherapy. It is stated that bibliotherapy is a usage form of literature that ensures that individuals identify their problems with the character in a book (cited in laquinta and Hipsky, 2006). In addition, it is described that it helps to create a healthy mood through literature (Davis \& Wilson, 1992). Cook, Earles - Vollrath and Ganz (2006) also argue that bibliotherapy is a good method that can be extended to the student individually. Likewise, they emphasize that it makes it easier for individuals to understand others and themselves. It is observed that bibliotherapy, which provides the opportunity to look at events from many different perspectives, provides an idea on how to cope with difficult situations in a healthy way. According to Cianciola (1965), books read help children to cope with life. It is argued that when they experience a situation similar to one they have read before, they face it with a deeper level of awareness. It is stated that this situation occurs thanks to the characters (cited in McTague, 1998). It is seen that bibliotherapy is used for various purposes in education. It is said that it especially helps students to improve their self-perception and self-esteem (Yeşilyaprak, 2008). It is also stated that it increases the probability of students to understand themselves and others. It is observed that it helps students to praise themselves in a realistic way. In addition, it is stated that it enables them to find different areas of interest (Leana-Taş̧̧ılar, 2012). It is also stated that it helps students cope with emotional pressures. It also shows the fact that students are not the only ones to deal with problems (ilter, 2015). It is also emphasized that bibliotherapy shows students that there are more multiple solutions to solve a problem. It also provides students with the opportunity to discuss their problems (Karacan Özdemir, 2016). It is also stated that bibliotherapy helps students face a challenging situation or solve their existing problems in a healthy way (Stamps, 2003). When developmental bibliotherapy is considered, it is emphasized that although it is not required to be applied by a specialist, there are some steps to be followed in terms of application in the classroom. Pardeck (1993) lists these steps as follows:

1. Determining the skill, behavior, situation or problem to be taught

2. Selecting the appropriate literary text / book

3. Asking students to read it

4. Conducting discussion after reading

With these steps, in primary education, students should be motivated with interesting materials and topics, and the teacher should make the necessary preparation (Hancock \& Pilonieta, 2009), and ensure that reading is done properly (in some cases, the teacher himself prefers reading out to the classroom) (Hancock \& Pilonieta, 2009). In this process, it is very important to carry out activities related to the book, to benefit from graphic organizers, and to discuss the book in monitoring studies, and to share the gained insights (Cook, Earles - Vollrath \& Ganz, 2006).

\section{USE OF BIBLIOTHERAPY METHOD AT SCHOOL}

The developmental bibliotherapy method can be used in different ways at school. Some of these are as follows: a) identifying areas that students are concerned about (such as bullying, adolescence), b) preventing social or emotional problems before they occur, c) providing information about problems or situations they may experience in later ages (Herbert \& Kent, 2000). 
One of the most important reasons why the use of bibliotherapy at school has effective results is that classroom and counseling teachers provide the opportunity to understand the academic, social and emotional needs of their students (Davis \& Wilson, 1992). Using a technique such as bibliotherapy at school also provides support for the emotional and social development of students. It is also stated that providing such a learning environment will have more permanent effects than a structured regular course (Herbert \& Furner, 1997).

It is emphasized that bibliotherapy is one of the techniques that can be used for ensuring that students with various learning problems and chronic health problems or attention issues are understood and accepted by other students at school. It is stated that by using this method the student who experiences problem will feel more comfortable and happy and that other students will behave in a more receptive manner towards the student who suffers from such problems (Pardeck, 1993).

Bruneau and Protivnak (2012) argues that bibliotherapy is a creative instrument that counselor teachers can use so that they can establish healthier communication with their students. Having students talk about their problems such as fear, mockery, and low self-perception through a book character, rather than directly on themselves, can help them to express their problems more easily. In addition, using this technique in situations such as coping with stressful situations, being a child of a divorced family, being adopted, moving, and the death of a close relative makes students feel that they are not alone (Öncü, 2012).

Davis and Wilson (1992) argued that bibliotherapy can be used in preventive counseling services as regards more serious problems such as substance addiction, violence and suicide that can be encountered at school. However, when discussing such severe situations, it is emphasized that attention should be paid to the attitudes of the students and that the person administering bibliotherapy should definitely refer the students to a specialist when they feel that their students are experiencing serious problems.

Taking a different perspective to the usage of bibliotherapy at school, Lutovac and Kaasila (2011) conducted a study with a pre-service teacher who suffered from mathematics anxiety in a very recent study. They helped this individual, who will become a classroom teacher in the future, overcome his anxiety by reading and discussing articles written in the field. In this context, it is seen that bibliotherapy is a technique that can be easily applied not only for students who have problems, but also for teachers and pre-service teachers (Yılmaz, 2014).

\section{USAGE OF CREATIVE DRAMA AT SCHOOL}

Creative drama is one of the teaching methods in topics used in education. It is reported that classes covered using creative drama method are more interesting and more fun as a general opinion. It is emphasized that teachers can improve students' knowledge, skills and attitudes positively with creative drama method (Başcı \& Gündoğdu, 2011).

It is seen that creative drama is defined as using improvisation, role-playing and creative drama techniques in educative terms (Adıgüzel, 2013; San, 2002), with a group study (Morgül, 1995; San, 1999; San, 2002; Üstündağ, 1998), by reorganizing a case, event, ideas, concept, behavior within one's own emotions and opinions, and animating experiences within playful processes. Creative drama, in particular, enables students to participate in the process by encouraging active engagement instead of listening to the lesson passively. In this case, it is stated that students' selfesteem and self-confidence increase, they discover their abilities, create learning environments where they make their own decisions, and see their social and personal development contributed (Susar-Kırmızı, 2009).

According to Adıgüzel (2000), several beneficial aspects of creative drama such as providing aesthetic development, developing critical thinking skills, encouraging collaborative work, and 
developing positive attitudes and behaviors towards educational purposes with communication skills are emphasized. In creative drama, it is stated that the individual also benefits from the values of the society and culture he / she lives in. As a matter of fact, the individual participates in the process by making use of his/her past experiences, impressions, traditions and customs during the practices. In this way, the dimension of learning by doing and living can be mentioned in terms of constructivist approach. As is known, it is said that the information learned by doing and living is more permanent (Aytaş, 2013). It can be emphasized that the quality of learning is quite high, as creative drama practices are minor rehearsals of life and provide students with the opportunity to cope with their perspective of the world they live in and the problem situations they will encounter. At the same time, it is seen that it has an effect on the development of students both affectively and cognitively (Toivanen, Komulainena, \& Ruismäkia, 2011). It is also stated that classroom activities affect metacognition (Sarıoğlu \& Kartal, 2017).

It is strongly emphasized that creative drama can be applied in all stages of education and all age groups. It has been observed that the diversity and fun dimension of the activities in the content of creative drama provide advantages in reaching educational goals by breaking down the boring barriers of instruction (Okvuran, 1993). It is emphasized that creative drama activities in the classroom environment include a student-centered process that contributes to personal development. It is mentioned that this process requires working with a group. Adıgüzel (2013) stated that creative drama cannot be done without a group. In addition, Morgül (1995) and Üstündağ (1998) stated that creative drama is a process that starts with the leader's guidance and continues with group interaction. Clusters are considered as another element in group work. These clusters can be chosen voluntarily or by the teacher. Group work enables individuals to empathize, gain common sense and develop in-group communication skills (Annarella, 1992). Thanks to intragroup communication, individuals have the opportunity to experience the lives of their groupmates in addition to their own lives (Aykaç \& Adıgüzel, 2011). Thus, they have the chance to gain from different experiences and practices. In order to gain these experiences, creative drama activities are carefully planned according to the goal, acquisition and learning outcomes. Action and movement are included in improvisation and role playing techniques in creative drama applications. Gürey and Adıgüzel (2013) emphasized that students would achieve a democratic attitude, develop an aesthetic perspective, be a part of a whole, act with a group, reveal creativity, and establish an emotional bond in the improvisation stage.

\section{DISCUSSION}

In the literature, there are many studies showing the positive achievements of the creative drama and bibliotherapy method used in education. The importance of integrating creative drama with bibliotherapy technique was seen in the acquisition of skills such as understanding emotions, empathy, active listening, and using body language, which are among the communication skills of students. In the literature, there are studies that reveal results that education provided with creative drama supports the communication skills of different groups. Colston (1985) found that creative drama education causes positive changes in verbal and social communication skills of individuals of different ages with structural developmental disorders. Netten (1995) found that storytelling, roleplaying and drama activities were effective in the communication and speaking skills of primary school sophomore students and their correcting their mistakes (cited in Özdemir, 2003). In his research, Yassa (1997) provided creative drama training to students to develop their social interaction skills and stated that this education gave students self-confidence, the sense of claiming their rights, controlling their emotions, empathy, and seeing different thoughts in the group. Jackson and Bynum (1997) concluded that drama education contributes positively to the social interactions of children with emotional disorders and behavioral disorders. Kempe (2003) 
emphasized in her study that drama has an important place in supporting speaking and listening skills.

In his study, Akoğuz (2002) experienced the effect of the creative drama education he gave to children aged 9-13 who volunteered to the Turkish Education Volunteers Foundation education parks and participated in creative drama workshops on children's communication skills. The researcher applied a 12-week creative drama education program to the children. At the end of his study, it was revealed that the program he applied developed the verbal communication, listening and non-verbal communication skills of 9-13 year old children at a high level. Öztürk (2006) examined the effect of the drama class taught with creative drama method on the verbal communication skills of prospective teachers in his study. The findings of the study showed that the verbal communication skills of the experimental group were significantly different from the control group consisting of the traditional drama students. This shows that the creative drama method increases the verbal communication skills of pre-service teachers. In addition, Bayrakçı (2007), in the study in which he examined the effect of creative drama activities on the development of communication skills in preschool, reached the conclusion that the creative drama method was effective in developing the communication skills of pre-school students.

In his study, Ergin (2003) examined the impact of "Communication Skills Education Program" which includes four communication skill areas, namely recognizing emotions, expressing emotions, listening, and making eye contact on pre-school children. At the end of the study, he determined that the communication skills of children who received education in the four mentioned areas was significantly different compared to the students who did not receive this education. In his study, Wardrope (2002) gave a business communication course to 280 businessmen who were managers. As a result of this course, he stated that there were positive developments in the communication skills of businessmen, especially in written communication. Korkut (1996) applied a communication skills training program aimed at improving the communication skills of high school students in his study. As a result of the application, it was found that it had a positive effect on high school students' evaluation of their communication skills. In the study of Deniz (2003) investigating the effect of communication skills training on the communication skill levels of primary school $8^{\text {th }}$ grade students, it was found that the communication skills training given was effective on the communication skills of the students.

In his study Epçapan (2012) determined that creative drama as a method of teaching has many strengths such as improving students' feelings of self-confidence, socialization, imagination and creative thinking skills, empathy, learning by doing, active participation in class, problem solving skills, individual relaxation, self-expression and communication skill, permanent learning, personal and spiritual development, and critical thinking.

In her study titled "Developing and Evaluating the Effectiveness of Creative Drama Based Cultural Adaptation Program in Higher Education", Besim (2019) revealed that the Northern Cyprus Culture Adaptation Program, which was created with the Creative Drama Method developed in the process of adapting to university life, made a positive contribution to the cultural adaptation process of university students. As can be seen, it can be said that at all levels of education, creative drama ensured that students actively participate in education, question, learn permanently, and have improved decision making and problem-solving skills. In addition, it can be emphasized that creative drama is a technique that helps students know themselves, express themselves, develop effective communication skills with others, and adapt to their environment.

In the literature, several studies can be found which state that bibliotherapy is a technique that helps individuals know themselves and reveal their potential. In his study, Semerci (2018) concluded that she benefited from the healing effect of bibliotherapy applications on the individual appealing to both the world of thinking and emotions, thus it is expected to meet the needs of the reader. Likewise, in his study titled "Investigation of the Effect of Bibliotherapy Use on Interpersonal 
Problem Solving Skills in 9-12 Years Old Children with Attention Deficit Hyperactivity Disorder and Special Learning Disabilities", Ozan (2017) concluded that the bibliotherapy education program revealed that the children significantly increased their interpersonal problem-solving skills. In the study titled "An Experimental Study: The Effect of the Biblio-psychological Counseling-Based SelfConfidence Development Program on the Self-Confidence Levels of 6th Grade Students", Özdemir (2016) found that Self-Esteem Development Program Based on Biblio-psychological Counseling provided a significant increase on the self-confidence scores of the participants in the experimental group. In Özdemir's research, it was revealed that bibliotherapy is a very effective method in increasing the self-confidence of students.

Sridhar and Vaughn (2000) emphasized that bibliotherapy technique increased the readingcomprehension skills, strengthened self-worth, behavioral development and problem-solving skills of students who had learning and behavioral problems. It is seen that in this way in the learning environments of biblio-therapy technique, students developed reading-related meaning, improved their self-concepts, effectively developed their behaviors in a positive way, and saw their problemsolving skills contributed. Alden, Lindquist, and Lubkeman (2003) stated in their study that bibliotherapy was a technique that could be used to increase students' reading motivation. As a result of their research, Campbell and Smith (2003) stated that books determined strategies and provided information as in the traditional therapeutic approach. They also stated that the clients developed insight by using them, raised awareness about their negative emotions and cognitions, found solutions and gained courage to use them in their daily lives.

Laquinta and Hipsky (2006) stated in their study that individuals can use bibliotherapy method to increase their self-esteem and to understand themselves better. In addition, they emphasized that teachers can use the bibliotherapy method to help their students solve problems and contribute to their alternative solutions. In this context, it can be said that the use of bibliotherapy method in education produces a highly effective result. In addition, Campbell, Krueger, and Vohs (2003) found that the bibliotherapy technique helped the individuals to have positive feelings and thoughts about themselves. In a similar study, Baumeister, Campbell, Krueger, and Vohs (2003) stated that the bibliotherapy technique contributed to the individual's positive feelings and thoughts. As a result of this research, it was observed that the bibliotherapy technique helped the individual to develop positive opinions about himself.

It is emphasized that bibliotherapy helps individual to gain information on his/her problems, gain insight, be motivated for speaking, gain new attitudes and values, notice that others have similar problems, and identify alternative ways of solution related to his/her problems (Pardeck, 1994). The importance of using books in the assistance process was mentioned. There are various preventive and developmental studies at international level on its use in schools to support selfconfidence. In these studies, self-confidence and coping-with-stress skills were examined (MeierJensen, 2001), the effect of biblio-counseling practices harmonized with curriculum on selfconfidence was examined (Garrett, 1984; Stringer, Reynolds, \& Simpson, 2003; Wadsworth, 2007), and it was found out that programs were effective in increasing the self-confidence scores of the participants.

In her study titled "The Effect of Bibliotherapy Training on Social-Emotional Skills, Reading Interest and Reading Motivation in Counselor Candidates", Başarı (2019) concluded that bibliotherapy education positively increased the emotional sensitiveness of psychological counselor candidates. It was found that there was a statistically significant difference between the pre-test and post-test scores the psychological counselor candidates received from the adult reading motivation scale in general and the recognition sub-dimension of the scale after the bibliotherapy training. As a result of the study, it was seen that the psychological counselors defined bibliotherapy as therapy with tales, self-knowledge and aiding in the development process. In addition, the study concluded that the participants saw bibliotherapy as an effective therapy method, a technique to 
help control emotions and overcome problems, and a way to mutually exchange ideas. As a result of the study, the participants expressed their opinions of "being socially active and raising awareness" about our social-emotional gains in bibliotherapy supported group guidance activities. At the same time, the participants emphasized that bibliotherapy training helped to face problems related to social emotional gains, helped the individuals to recognize and realize themselves emotionally, and contributed to being more sociable and talkative in communication. Regarding the contribution of bibliotherapy training to social emotional gains, the participants put forward the view that it provided a real perspective on life, was solution-oriented, and helped to be a more thoughtful person. In addition, the research revealed that bibliotherapy education contributes to the individuals to find themselves in tales and to agree with their peers. As a result of the study, it was seen that the use of bibliotherapy technique in education was very beneficial for students.

\title{
CONCLUSION
}

In conclusion, several studies have been discussed that conclude that the use of creative drama and bibliotherapy technique in education has a high effect. In each study, the importance of the use of both techniques is emphasized in the individual's finding himself / herself, gaining insight, and discovering many aspects that he/she has not known until today. It was observed that especially creative drama and bibliotherapy contributed to individuals' decision making and problem solving skills in their education processes. In addition, it can be said that creative drama and bibliotherapy techniques contribute to the development of social-emotional skills and effective communication of students. It can especially be stated that creative drama and bibliotherapy method are also very effective in developing the empathy skills of students.

\section{RECOMMENDATIONS}

As a result of the literature review conducted, the following recommendations can be presented as regards the employment of creative drama and bibliotherapy techniques in education:

a) Since creative drama is a method based on in-group interaction, it is recommended to be used as a method in all courses in order to improve communication skills of students.

b) B) It is recommended to integrate bibliotherapy with creative drama in education programs related to other social skills such as problem solving and decision making that individuals use in their lives.

c) It is recommended to offer bibliotherapy education at pre-school, primary, secondary and university levels.

d) It is thought that the use of bibliotherapy technique, which is known to have a high preventive effect, will be beneficial in schools as a preventive measure after a training to be given to teachers.

e) Considering that creative drama can be applied to all age groups and can be used actively, it is often recommended to be considered as a method in adult education.

f) It is recommended to use films (synetherapy method) in addition to literary works such as books, tales and stories in bibliotherapy applications.

\begin{abstract}
Authors' Contributions: Şengül Başarı: conception and design, acquisition of data, analysis and interpretation of data, drafting the article, critical review of important intellectual content. Seçil Besim Ayhan: conception and design, acquisition of data, analysis and interpretation of data, drafting the article, critical review of important intellectual content. All authors have read and approved the final version of the manuscript.
\end{abstract}

Ethics Approval: Not applicable.

Acknowledgments: Not applicable. 


\section{REFERENCES}

Adıgüzel, H. Ö. (1993). The relationship between play and creative drama. Unpublished Master Thesis, Ankara University, Institute of Educational Sciences, Department of Education Programs and Instruction, Ankara.

Adıgüzel, H. Ö. (2000). The importance and necessity of training creative drama teachers. Education and Life Journal, $5,17-18$

Adıgüzel, H. Ö. (2006). Creative drama concept, Components and Stages. Creative Drama Magazine, 1, 17-31.

Adıgüzel, Ö. (2013). Creative drama in education. Ankara: Pegem Academy.

Akin, M. (1993). The effect of creative drama education on the socialization levels of elementary school 3rd grade students at different socio-economic levels. Unpublished Master Thesis, Ankara University, Institute of Educational Sciences, Ankara.

Akoğuz, M. (2002). The effect of creative drama in improving communication skills. Unpublished Master's Thesis, Ankara University, Institute of Educational Sciences.

Alden, K., Lindquist, J. M. and Lubkeman, C. A. (2003). Using literature to increase reading motivation. (ERIC Document Reproduction Service No. 481442).

Annarella, L. A. (1992). Creative drama in the classroom. Washington D.C.: Office of Educational Research and Improvement.

Aykaç, M. \& Adıgüzel, Ö. (2011). The effect of using creative drama as a method in social studies course on student success. Kastamonu Education Journal, 19 (1), 297-314.

Aytaş, G. (2013). The role of creative drama in perceptual learning. Journal of Mother Tongue Education, 1 (1), 101106.

Başarı, Ş. (2019). Bibliotherapy Social-Emotional Skills, Reading Interest and Its Effect on Reading Motivation in Counselor Candidates. Unpublished Doctoral Thesis. Near East University. Institute of Education Sciences.

Başçı, Z., \& Gündoğdu, K. (2011). Attitudes and views of teacher candidates towards the drama lesson: Atatürk University example. Elementary Education Online, 10 (2), 454-467.

Baumeister, R. F., Campbell, J.D., Krueger, J. I. \& Vohs, K. D. (2003). Does high self-esteem cause better performance, interpersonal success, happiness, or healthier lifestyles? Psychological Science in the Public Interest, 4 (1), 1-44.

Bayrakçı, M. (2007). The effect of creative drama activities on the development of communication skills in preschool. Unpublished Master's Thesis, Kafkas University, Institute of Social Sciences.

Besim, S. (2019). Developing and Evaluating the Effectiveness of Creative Drama Based Cultural Adaptation Program in Higher Education. Unpublished Doctoral Thesis. Near East University. Institute of Education Sciences.

Bruneau, L., \& Protivnak, J. J. (2012). Adding to the toolbox: Using creative interventions with high school students. Journal of School Counseling, 10(9). Retrieved from http://jsc.montana.edu/articles/v10n9.pdf.

Campell, L. F. and Smith, T. P. (2003). Integrating self-help books into psychotherapy, Journal of Clinical Psychology/ın Session, 59 (2). 177-186.

Cartledge, G. and Milburn, J. F. (1983). Social skills assessment and teaching in the schools. Advances in School Psychology, 3, 175-235.

Cook, K. E., Earles-Vollrath, T., \& Ganz, J.B. (2006). Bibliotherapy. Intervention in School and Clinic, 47(2), 91-100.

Davis, K., \& Wilson, T. L. (1992). Bibliotherapy and children's award - winning books. (ERIC Document Reproduction Service No. 354470). 
Deniz, i. (2003). The effect of communication skills training on the communication skill levels of primary school 8th grade students. Unpublished Master's Thesis, Gazi University, Institute of Educational Sciences.

Epçaçan, C. (2012). Faculty of Education Students' Views on the Effectiveness of Creative Drama Method. Ekev Academy Journal, 16 (52). 281-296.

Ergin, H. (2003). The effect of the communication skills training program on the communication skills levels of preschool children. Unpublished Master's Thesis, Istanbul University, Institute of Social Sciences.

Garrett, J. E. (1984). The effects of bibliotherapy on self-concepts of children and youth in an institutional Setting. Doctoral dissertation, Ball State University, Indiana.

Genç, H. N. (2003). Reception of creative drama in education. Hacettepe University Journal of Education, 24, $196-205$. Gürey, B. \& Adıgüzel, Ö. (2013). Developing dance movement skills and body awareness with creative drama. Creative Drama Magazine, 8 (15), 1-27.

Hancock, S. D., \& Pilonieta, P. (2009). Visiting day: creating bridges through bibliotherapy and children's literature. Literatures of the Diaspora, 8(57), 39-52.

Heathcote, D. and Wagner, B. (1990). Drama as a learning medium. (6. edition). Stanley Thornes, Publishers Ltd.

Herbert, T. P., \& Furner, J. M. (1997). Helping high ability students overcome math anxiety through bibliotherapy. Journal of Secondary Gifted Education, 8, 164-179.

Herbert, T. P., \& Kent, R. (2000) Nurturing social and emotional development in gifted teenagers through young adult literature. Roeper Review, 22(3), 167-171.

laquinta, A., \& Hipsky, S. (2006). Practical bibliotherapy strategies for the inclusive elementary classroom. Early Childhood Education Journal, 34(3), 209-213.

Iilter, B. (2015). The effect of bibliotherapy technique on the perfectionism of gifted children. Unpublished master's thesis, Fatih Sultan Mehmet Vakıf University, Istanbul.

Jackson, J.T., \& Bynum, N. (1997). Drama: A teaching tool for culturally diverse children . Journal Of Instructional Psychology, 24( 3),158-168.

Johnson, L. and O'Neill, C. (1984). Dorothy Heathcote: Collected writings on education and drama. Essex: Anchor Brendon Ltd.

Kaf, Ö. (2000). The effect of creative drama method on gaining some social skills in life studies lesson. Ç.Ü. Journal of the Institute of Social Sciences, 6 (6), 173-184.

Karacan Özdemir, N. (2016). An experimental study: The effect of a bibliological counseling program on selfconfidence levels of 6th grade students. Elementary Education Online, 15 (1), 136-147. doi: http:

//dx.doi.org/10.17051/io.2016.59570.

Kelly, J. A. (1982). Social-skills training: A practical guide for interventions. New York: Springer Publishing Company.

Kempe, A. (2003). The role of drama in the teaching of speaking and listening as the basis for social capital. Research in Drama Education, 8 (1), 65-78.

Korkut, F. (1996). Development of communication skills assessment scale: reliability and validity studies. Psychological Counseling and Guidance Journal, 2 (7), 18-23.

Leana-Taşcilar, M. Z. (2012). Use of bibliotherapy in classes with gifted and talented students: A model proposal. Turkish Journal of Giftedness and Education, 2 (2), 118-136.

Lutovac, S., \& Kaasila, R. (2011). Beginning a pre-service teacher's mathematical identity work through narrative rehabilitation and bibliotherapy. Teaching in Higher Education, 16(2), 225-236. 
McTague, K. (1998). Children's literature bibliotherapy and learning problems. (ERIC Document Reproduction Service No. 424560).

Meier-Jensen, W. (2001). The effects of bibliotherapy on reducing stress/worry in inner-city first grade students. Master thesis, The University of Wisconsin, Stout. Retrieved March 20, 2008, from www.uwstout.edu/lib/thesis/2001/2001meier-jensenw.pdf.

Morgül, M. (1995). Learn by living, playing with creative drama. Istanbul: Ya-Pa Yayın Pazarlama San. ve Tic. A.S.

O’Neill, C. ve Lambert, A. (1995). Drama structures: A practical handbook for teachers. Hutchinson, London.

Okvuran, A. (1993). The effect of creative drama education on empathic skill and empathic disposition levels. Unpublished Master Thesis, Ankara University Institute of Educational Sciences, Ankara.

Öncü, H. (2012). Use of bibliotherapy method for psychological counseling and guidance in schools. Turkey Social Research Journal, 16 (1), 147-170.

Oral, G. (2002). A program to encourage students' social participation in primary education. Boğaziçi University Journal of Education, 19(2), 30-44.

Özan, G. B. (2017). Investigation of the Effects of Bibliotherapy Use on Interpersonal Problem Solving Skills in 9-12 Years Old Children with Attention Deficit Hyperactivity Disorder and Special Learning Disabilities. Istanbul Commerce University. Social Sciences University. Published Master Thesis.

Özdemir, L. (2003). The effect of creative drama lesson on emotional intelligence development. Unpublished Master Thesis, Uludağ University, Institute of Social Sciences.

Özdemir, N. K. (2016). An Experimental Study: The Effect of the Self-Confidence Development Program Based on Biblio-psychological Counseling on the Self-Confidence Levels of 6th Grade Students. Elementary Education Online, 15 (1): 136-147.

Öztürk, A. (2006). The effects of the theater lesson to be taught with creative drama method on the verbal communication skills of prospective teachers. Second edition. (Ed: H. Ö. Adıgüzel) Creative Drama Articles 1985-1998. Ankara: Naturel Publishing.

Pardeck, J. T. (1994). Using literature to help adolescents cope with problems- bibliotherapy. Adolescence, 29 (114), 421-427.

Pardeck, J. T. (1993). Literature and adoptive children with disabilities. Early Child Development and Care, 91, 33-39.

Sağlam, T. (2004). Dramatic education: purpose? Is it a vehicle? Theater Studies Journal, 17, 4-22.

San, i. (1996). A method that develops creativity and a discipline that raises the creative individual: Educational creative drama. New Turkey Magazine Special Issue of Education, 2 (7), 148-160.

San, i. (1999). yesterday and today with creative drama activities in Turkey. Republic and child. II National Children's Culture Congress. (267-273). (Pub. Pre: Bekir Onur), Ankara: Ankara Univ. Child Culture Research and Application Center Yay.

San, i. (2002). Creative Drama in Education, Creative Drama, 1985-1995, Writings, (1st volume). Ankara: Naturel Publishing.

Sorias, O. (1986). Social skills and assessment methods. Journal of Psychology, 5 (20), 24-29.

Sridhar, D. and Vaughn, S. (2000). Bibliotheraphy for all: Enhancing reading comprehension, self-concept, and behavior. TEACHING Exceptional Children,33(2), 74-82.

Stamps, L. S. (2003). Bibliotherapy: How books can help students cope with concerns and conflicts. The Delta Kappa Gamma Bulletin, Fall, 25-29. 
Stringer, S. J., Reynolds, G. P. \& Simpson F. M. (2003). Collaboration between classroom teachers and a school counselor through literature circles: Building self-esteem. Journal of Instructional Psychology, Database: Psychological and behavioral sciences collection, 00941956.

Susar-Kırmızı, F. (2009). The effect of creative writing activities based on creative drama method on attitude towards writing in Turkish lesson. Creative Drama Magazine, 4 (7) 1-18.

Toivanena, T., Komulainena, K. \& Ruismäkia, H. (2011). Drama education and improvisation as a resource of teacher student's creativity. Procedia Social and Behavioral Sciences 12, 60-69.

Uşaklı, H. (2014). Drama and Communication Skills Theory, Research, Application. (3rd Edition) Nobel Publishing. Üstündag, T. (1998). Elements of creative drama education program. Education and Science, 22 (107), 28-35.

Uysal, F. N. (1996). Investigation of the effect of creative drama activities on social development of children aged 5-6 years old in kindergarten. Unpublished Master Thesis, Ankara University, Institute of Social Sciences, Ankara.

Vural, R., \& Somers, J. W., (2012). Drama in Primary Education for Humanist Primary Education Programs: Theory and Practice. (2nd Edition) Pegem Academy.

Wadsworth N. (2007). Addressing self-esteem through the use of bibliotherapy in literature circles. An Action Research Project submitted to the faculty of the Graduate Program for Education, Westminster College, Salt Lake City, Utah.

Wardrope, W. J. (2002). Department chairs' perceptions of importance of business communications skills. Business Communication Quarterly, 65 (4), 60-72.

Westwood, P. (1993). Commonsense methods for children with special needs strategies for the regular classrom. London.

Yassa, N. A. (1997). A study of the effect of drama education on social Interaction in high school students. Unpublished Doctoral Dissertation, Ontario: Lakehead University.

Yeşilyaprak, B. (2008). Bibliotherapy: Treatment with reading. Offspring, 82, 20-22.

Yılmaz, M. (2014). Recovery with knowledge: Bibliotherapy. Turkish Librarianship, 28 (2), 169-181.

Yüksel, G. (2001). Social skill as the behavior that teachers should have. Journal of National Education, 150. Retrieved on 17.01.2007 from http://yayim.meb.gov.tr/dergiler/150/kayikci.htm.

Received: 29 March 2021 | Accepted: 30 April 2021 | Published: 11 May 2021

This is an Open Access article distributed under the terms of the Creative Commons Attribution License, which permits unrestricted use, distribution, and reproduction in any medium, provided the original work is properly cited. 